\title{
DESAIN PERHIASAN KERAMIK KOMBINASI LOGAM DENGAN INSPIRASI FLORA DAN FAUNA KHAS JAWA BARAT
}

\author{
Maevara Audrey Saraswati ${ }^{1}$, Sulistyo Setiawan ${ }^{2}$ \\ 1 Program Studi Desain Produk, Fakultas Arsitektur dan Desain, Institut Teknologi Nasional, Bandung. \\ 2 Program Studi Desain Produk, Fakultas Arsitektur dan Desain, Institut Teknologi Nasional, Bandung. \\ Email: varaaudreys@mhs.itenas.ac.id, sulistyo@itenas.ac.id
}

\begin{abstract}
Abstrak
Perkembangan desain perhiasan yang cepat dan dinamis memacu desainer berkolaborasi bersama pengrajin untuk terus mengembangkan inovasi serta keunikan desain perhiasannya sebagai ciri khas dan kekuatan sebuah industri. Salah satu kekayaan Indonesia yang dapat diandalkan menjadi sebuah inspirasi ialah keanekaragaman flora dan fauna khas daerah yang ada di Nusantara. Dari upaya tersebut diharapkan industri dapat bersaing di dalam pasar domestik maupun internasional. Selain itu, penggunaan material keramik yang belum banyak digunakan oleh industri perhiasan juga berperan sebagai pembeda antara industri yang satu dengan industri pesaingnya. Tujuan dilakukannya pengembangan desain perhiasan menggunakan material keramik dan logam ialah untuk menghasilkan alternatif inovasi produk perhiasan keramik mix material. Metode penelitian desain yang digunakan adalah eksplorasi bentuk dengan pendekatan semantik rupa. Hasil yang diperoleh dari penelitian ini adalah desain perhiasan keramik dapat dikembangkan oleh industri sebagai salah satu peluang untuk terus berinovasi seiring dengan terus berkembangnya industri fashion.
\end{abstract}

Kata kunci: pengembangan, desain perhiasan, keramik, logam, flora dan fauna khas Jawa Barat.

Abstract

The fast and dynamic growth of jewelry design makes designers collaborate with the artisan to develop innovation and uniqueness of jewelry design as characteristics and industrial's strength. One of Indonesia's riches that can be relied upon to be an inspiration is the diversity of typical flora and fauna of the regions in the archipelago. From these efforts, the jewelry industry can compete in both domestic and international markets. Besides, ceramic materials have not been using by the jewelry industry also acts as a differentiator between one business and its competitors. The purpose of developing jewelry designs using ceramic and metal materials is to produce innovative ceramic mix material jewelry products as an alternative product in the jewelry industry. The design research method used was shape exploration with a visual semantic approach. The result of this research is ceramic jewelry design can be used by the industry as an opportunity to keep innovate along with the development of fashion industry.

Keywords: development, jewelry design, ceramic, metal, flora and fauna typical of West Java.

\section{Pendahuluan}

Perkembangan industri fashion saat ini lebih dinamis karena bergantung pada tren dan fenomena sosial tertentu. Salah satu bagian dari industri fashion adalah industri perhiasan yang memiliki beberapa jenis seperti antinganting, kalung, dan cincin. Produk perhiasan digunakan masyarakat untuk menunjang penampilan dalam kegiatan sehari-hari maupun acara tertentu, selain itu produk perhiasan digunakan sebagai bentuk ekspresi diri dimana perhiasan divisualisasikan dalam bentuk rupa yang terpengaruh oleh lingkungan dalam proses pembuatannya. Husni Muhammad menyatakan bahwa perhiasaan dibuat sebagai "bumbu" rasa keindahan maupun perasaan terhadap rasa estetika [1]. Produk perhiasan tersebut pada umumnya identik dengan material logam. Fenomena ini membuat para industri perhiasan dituntut peka dan mengikuti perkembangan tren. Indonesia memiliki keanekaragaman kekayaan nusantara berupa flora, fauna, maupun budaya yang dapat divisualisasikan dalam bentuk perhiasan, karena perhiasan mempunyai nilai tambah (added value) dari segi emosi maupun simbolik yang lebih dibandingkan produk fungsi lainnya [2].

Flora dan fauna yang terdapat di Indonesia memiliki berbagai jenis khususnya di daerah Jawa Barat seperti sawo kecik, rhododendron, gandaria, kepuh, Rafflesia patma, dan anggrek bulan. Selain itu untuk jenis fauna adalah macan tutul, owa jawa, badak jawa, surili, burung cerek, elang jawa, dan kodok darah. Dari beberapa jenis flora dan fauna tersebut memiliki karakteristik visual yang dapat menjadi inspirasi baru dalam pengembangan produk

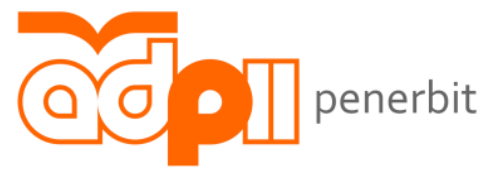

Penerbit Aliansi Desainer Produk Industri Indonesia 
perhiasan. Namun pada beberapa produk perhiasan yang terdapat di pasaran desainnya masih cenderung menyalin bentuk asli sehingga terlihat monoton. Menurut penelitian yang dilakukan oleh McKinsey \& Company, 2014 menyatakan bahwa perkembangan industri perhiasan kemungkinan akan berasal dari industri nonperhiasan seperti industri high-end apparel atau leather goods [3]. Salah satu industri yang memiliki peluang dalam mengembangkan produk perhiasan adalah industri keramik.

Keramik merupakan material alam yang terbuat dari tanah liat. Produk kriya keramik yang berkembang saat ini kerap kali dibagi menjadi dua yaitu jenis keramik pakai (craft as business) dan keramik seni (fine art ceramic) yang digunakan sebagai bentuk ekspresi diri [4]. Produk keramik pakai yang dihasilkan berupa home décor dan tableware, sementara untuk keramik seni berupa instalasi serta patung. Jenis tanah yang sering digunakan adalah earthernware, stoneware, dan porcelain. Dari beberapa jenis tanah tersebut memiliki keunggulan karakteristik yang kuat, tahan air, dan mudah dibentuk. Pada proses pengolahan material keramik dibagi menjadi beberapa langkah yaitu, pengolahan bahan mentah, pembentukan, pengeringan, pewarnaan, dan pembakaran. Dari proses pengolahan tersebut akan menghasilkan produk perhiasan yang memiliki karakteristik baru seperti warna, inovasi bentuk, corak, dan eksklusifitas tinggi dikarenakan proses pengolahanya yang bersifat handmade. Menurut Raniah A. Albugis, sejumlah konsumen baru memahami bahwa material keramik dapat dimanfaatkan sebagai produk perhiasan [5].

Maka dari itu penulis berharap dapat mengaplikasikan potensi material keramik ke dalam bentuk produk perhiasan melalui kegiatan eksplorasi bentuk dengan pendekatan metafora pada flora dan fauna khas Jawa Barat. Menggunakan material keramik yang belum umum digunakan serta objek inspirasi yang bersifat endemik akan menimbulkan rasa penasaran terhadap perhiasan keramik tersebut. Selain itu, diharapkan perhiasan keramik dapat dimanfaatkan sebagai alternatif kebaruan visual dalam industri perhiasan dan keramik tanpa menghilangkan karakteristik material serta identitas perhiasan itu sendiri. Diharapkan pula pada kegiatan tersebut dapat memberikan nilai jual dan fungsi pada perhiasan keramik sehingga dapat bersaing dengan industri perhiasan lainnya.

\section{Metodologi}

Metode penelitian yang digunakan penulis untuk mengembangkan desain perhiasan keramik adalah menggabungkan tahapan identifikasi dengan metode pendekatan semantik rupa. Dilakukan kegiatan eksplorasi bentuk dengan pendekatan metafora yang memanfaatkan objek tertentu seperti objek natural berupa hewan, tumbuhan, manusia, dan lainnya [6]. Objek natural yang dimanfaatkan oleh penulis adalah kekayaan flora dan fauna endemik Jawa Barat.

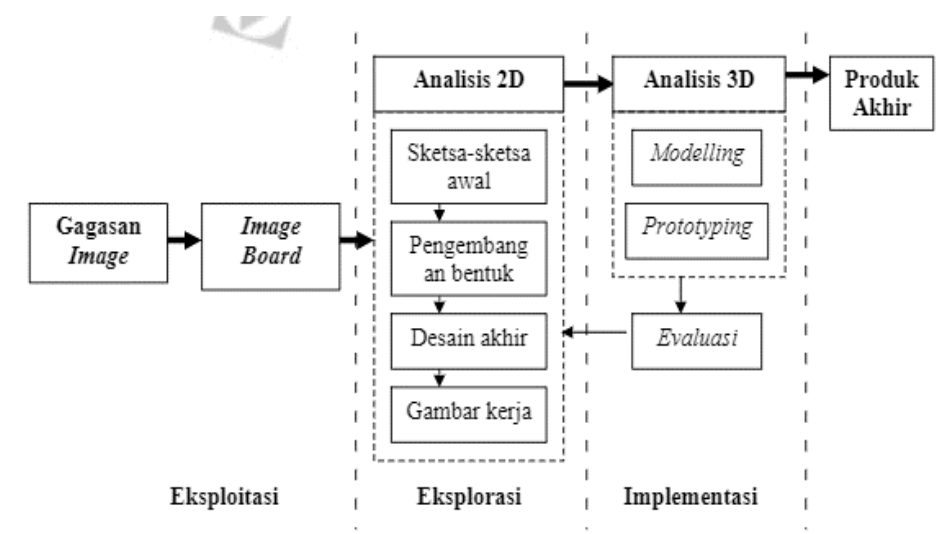

Gambar 1 Alur pengembangan desain sebuah produk dengan pendekatan semantik rupa. (Sumber: Arif Waskito, 2014)

\subsection{Identifikasi}

Tahapan pertama yang dilakukan dalam fase identifikasi adalah menentukan peluang dari industri keramik menggunakan strategi SWOT. Proses penentuan peluang pun mempertimbangkan berbagai aspek desain seperti aspek material, aspek fungsi dan aspek produksi yang dimiliki oleh industri.

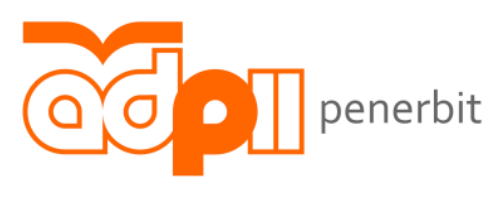

Penerbit Aliansi Desainer Produk Industri Indonesia 


\subsection{Eksploitasi}

Dalam tahapan ini penulis akan menelusuri karakteristik flora dan fauna endemik Jawa Barat sehingga didapatkan identitas yang kuat dari visual yang dimiliki oleh flora dan fauna yang menjadi objek penelitian. Dilakukan dengan menggunakan metode secondary research dan pendekatan metafora untuk menghasilkan gagasan image yang akan divisualisasikan ke dalam bentuk image board.

\subsection{Eksplorasi}

Identitas khas yang telah didapatkan pada proses eksploitasi diwujudkan ke dalam bentuk sketsa-sketsa dua dimensi maupun tiga dimensi. Kegiatan eksplorasi kerap kali dilakukan pada berbagai macam material baik itu material alam maupun buatan. Eksplorasi bentuk dapat diaplikasikan terhadap material kayu, logam, kaca ataupun dapat diaplikasikan pada material lembaran seperti akrilik [7]. Pada tahap ini penulis melakukan eksplorasi bentuk untuk mendapatkan bentuk modul perhiasan keramik yang tepat dengan menggunakan pendekatan metafora, sehingga modul perhiasan yang dihasilkan tetap memiliki identitas dari flora dan fauna yang dijadikan sumber inspirasi.

\subsection{Implementasi}

Proses analisis tiga dimensi dilakukan menggunakan software 3D modelling berdasarkan modul-modul keramik hasil uji coba pada proses sebelumnya. Evaluasi desain dilakukan melalui penyebaran kuisioner kepada target pengguna yang telah ditetapkan, setelah melewati proses evaluasi desain didapatkan desain akhir perhiasan keramik yang memiliki karakteristik sesuai dengan sumber inspirasi serta dapat diproduksi oleh industri sebagai salah satu bentuk inovasi pengembangan perhiasan keramik yang baru. Hasil dari proses implementasi ini memperjelas harapan desain perhiasan keramik yang akan dihasilkan nantinya

\section{Pembahasan}

Industri keramik memiliki peluang untuk menghasilkan produk perhiasan keramik dengan material yang mereka miliki, salah satunya adalah stoneware. Stoneware atau batuan merupakan keramik yang memiliki suhu pembakaran $1150-1300^{\circ} \mathrm{C}$ dengan bahan dasar tanah liat bersifat silica (kaca) yang dapat berubah fisik. Stoneware memiliki sifat tidak menembus cahaya serta memiliki permeabilitas yang rendah sehingga material ini tidak menyerap air seperti tembikar [8]. Material tersebut dapat melewati dua cara proses penggarapan permukaan yaitu, glasir dan pencampuran warna menggunakan mineral-mineral alam seperti chromium, kobalt, tembaga, nikel, dan mineral lainnya. Sehingga corak atau warna visual yang dihasilkan pun akan beragam. Perhiasan keramik yang telah diproduksi oleh industri dicantumkan sebagai berikut:
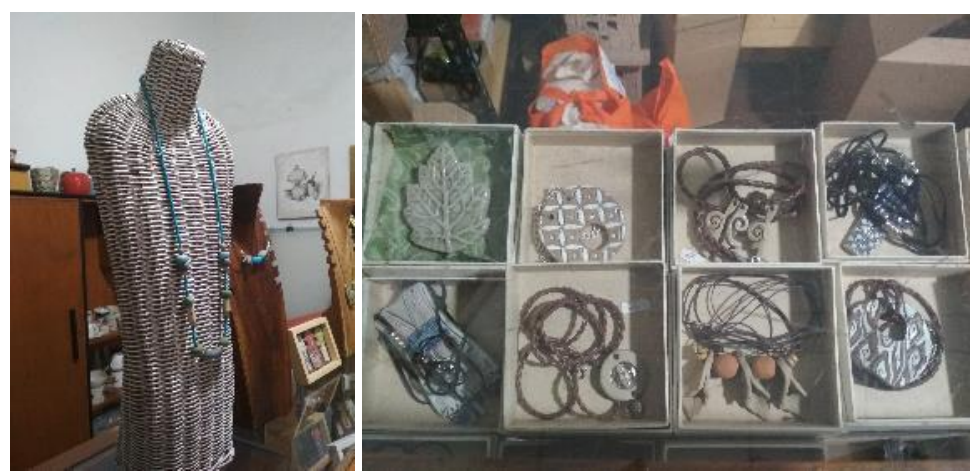
Jurnal Desain Indonesia Vol. 03 no. 01 - Aliansi Desainer Produk Industri Indonesia

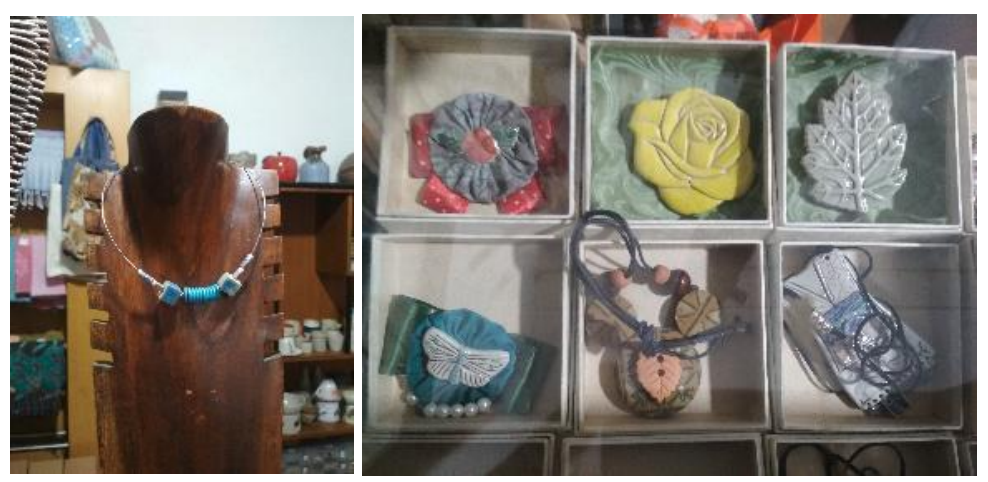

Page $\mid 60$

Gambar 2 Contoh produk perhiasan keramik yang ada di industri keramik. (Sumber: Dokumentasi pribadi)

Pada gambar perhiasan keramik di atas desain perhiasan mayoritas masih meniru bentuk asli dari sumber inspirasinya yaitu bentuk alam dan motif batik, sehingga bentuk modul perhiasan masih cenderung monoton. Material utama yang digunakan oleh industri adalah terracotta dan stoneware dengan teknik handbuild dan cetak padat, serta menonjolkan penggarapan permukaan menggunakan teknik glasir. Sementara material pendukung yang digunakan untuk menunjang modul keramik adalah tali kulit, kain, dan kawat logam.

\subsection{Pertimbangan aspek desain}

Proses desain dilakukan untuk menghasilkan desain perhiasan keramik yang memiliki karakteristik khas flora dan fauna khas Jawa Barat yang terpilih. Proses tersebut dilakukan dengan mempertimbangkan beberapa aspek desain yang akan dikaji yaitu:

\subsubsection{Aspek material}

Stoneware memiliki plastisitas yang baik dan tingkat penyusutannya rendah, membuat proses pembentukan modul menjadi lebih mudah karena dikerjakan secara handmade. Selain tanah liat stoneware, material logam yang akan dikombinasikan dengan material keramik tersebut adalah logam kuningan. Kuningan dinilai sesuai untuk dijadikan material perhiasan dikarenakan hal berikut:

- Mudah dibentuk, kuningan lebih mudah untuk dibentuk dibandingkan jenis logam tembaga dan perunggu.

- Tahan air, dikarenakan pengguna kemungkinan akan berkeringat saat menggunakan perhiasan dalam jangka waktu tertentu. [9]

- $\quad$ Ringan untuk ditopang oleh anggota tubuh yang diberi perhiasan.

Kombinasi material ini bertujuan untuk meningkatkan nilai jual perhiasan keramik. Karena penggunaan logam yang telah umum digunakan pada produk perhiasan membuat material ini dapat diperhitungkan sebagai material pendukung dari produk perhiasan keramik. Hal yang harus diperhatikan ialah pengolahan material logam memiliki waktu yang cukup lama dikarenakan bersifat handmade dan memerlukan ketekunan serta kesabaran dalam tiap pembuatannya, sehingga produk perhiasan keramik kombinasi logam ini bersifat ekslusif. [2]

\subsubsection{Aspek produksi}

Pembuatan modul keramik dilakukan dengan beberapa tahapan yaitu pengolahan bahan utama keramik dan bahan khusus pewarnaannya, proses pembentukan (forming), penggarapan permukaan, pengeringan, serta pembakaran. Sementara itu pada material kuningan dilakukan proses patri untuk membuat kerangka dan kuncian untuk modul keramik yang sudah jadi.

\subsubsection{Aspek fungsi}

Selain digunakan masyarakat untuk menunjang penampilan dalam kegiatan sehari-hari maupun acara tertentu, perhiasan dapat digunakan sebagai gaya hidup masyarakat. Khususnya untuk perempuan, perhiasan sebagai sarana untuk menunjukan status sosialnya seolah perhiasan menjadi produk yang wajib digunakan dalam keseharian serta pada acara-acara tertentu. [9]

\subsubsection{Aspek pengguna}

Target pengguna dispesifikan menjadi perempuan dewasa pada usia 21-30 tahun yang berada di usia produktif bekerja dan berada pada tingkat ekonomi menengah ke atas. Pengguna memiliki kebutuhan lebih yaitu kebutuhan sosial serta penghargaan. Selain itu, pengguna memiliki karakteristik unik/ eksentrik dan ketertarikan lebih terhadap fashion. Berdasarkan analisis pengguna, mereka kerap menggunakan perhiasan untuk melengkapi penampilan mereka saat berpergian, menghadiri acara yang bersifat semi formal dan formal, untuk kebutuhan

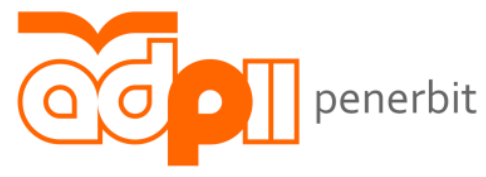

Penerbit Aliansi Desainer Produk Industri Indonesia 
performance, dan pemotretan/ foto. Jenis perhiasan yang kerap kali mereka gunakan adalah kalung jenis choker dan collar dengan diameter $16 \mathrm{~cm}$, anting-anting berjenis drop, dangle, dan stud dengan panjang $1-5 \mathrm{~cm}$, jepit, dan gelang tangan.

\subsubsection{Aspek bentuk}

Dikarenakan target pengguna merupakan perempuan yang memiliki ketertarikan lebih terhadap fashion, analisis bentuk dilakukan berdasarkan referensi dari artikel Vogue perihal trend perhiasan pada tahun 2021 yang bisa dilihat pada pranala berikut: https://www.vogue.com/article/spring-2021-jewelry-trend-report
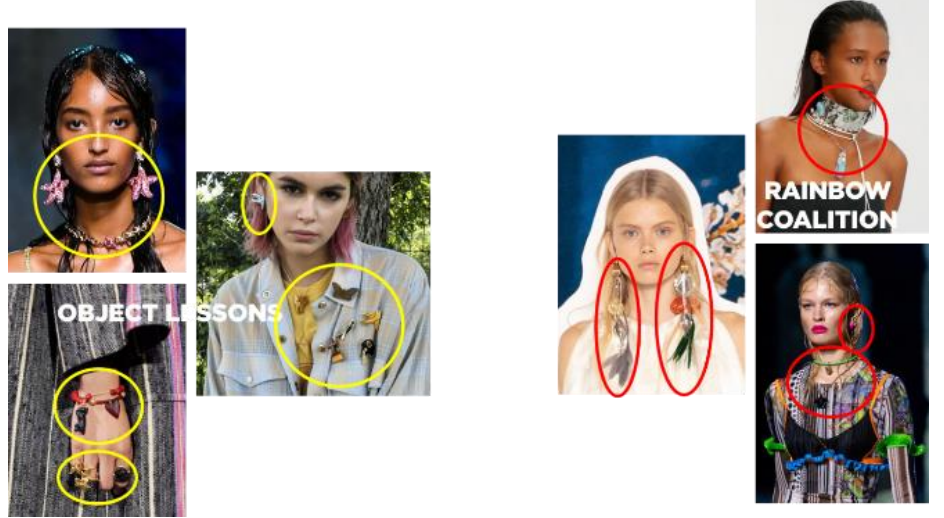

Gambar 3 Salah dua tren perhiasan spring 2021 berdasarkan artikel majalah vogue. (Sumber: www.vogue.com)

Menurut artikel majalah Vogue, pada tren Object lessons penggunaaan objek figuratif pada beberapa perhiasan milik brand fashion ternama membuat perhiasan tersebut memiliki kesan fun to wear, sementara pada tren Rainbow coalition penggunaan banyak warna pada perhiasan membuat penampilan terkesan lebih hidup. [10]

\subsection{Image board}

Pencarian citra bentuk dilakukan dengan menggunakan pendekatan metafora. Proses tersebut kerap kali diawali dengan menggabungkan beberapa gambar dari objek inspirasi ke dalam bentuk image board yang di dalamnya terdapat gambar-gambar objek dari beberapa sudut pandang untuk kemudian ditelaah dan ditemukan karakteristik bentuk yang khas dari objek bersangkutan [6].

Objek inspirasi yang penulis manfaatkan karakteristiknya untuk desain perhiasan adalah Rafflesia patma, anggrek bulan jawa, macan tutul jawa, dan owa jawa. Dengan analisis visual yang tepat dan benar serta mempertimbangkan kemampuan material dan proses produksi, keunikan-keunikan dari objek inspirasi akan menghasilkan sebuah kebaruan visual tanpa menghilangkan identitas-identitas unik yang dimiliki oleh flora dan fauna endemik tersebut.
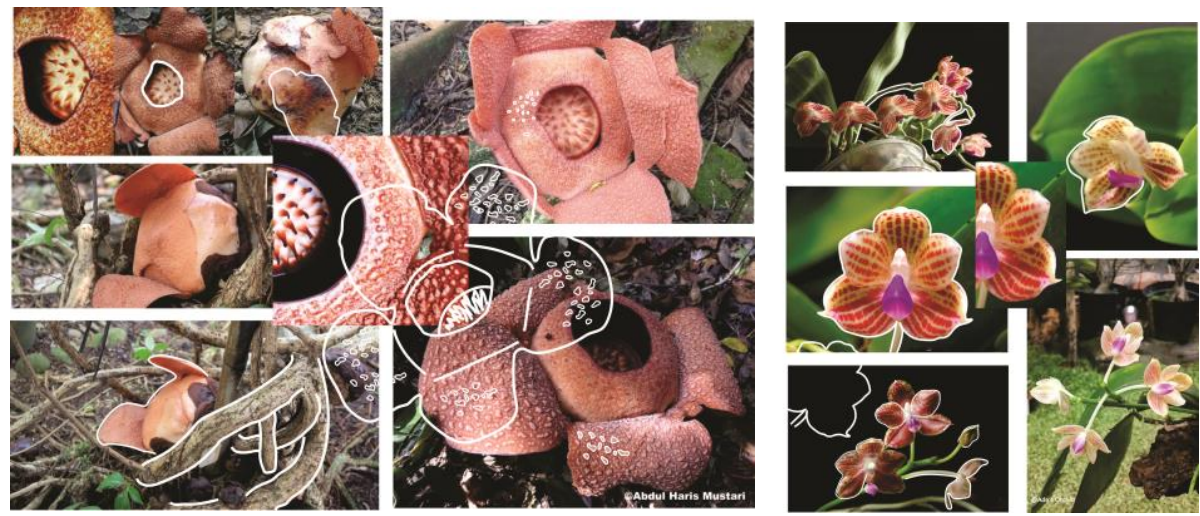

Gambar 4 Image board Rafflesia patma dan anggrek bulan jawa khas Jawa Barat. (Sumber: google images)

Dari hasil analisis image board pada Rafflesia patma dan anggrek bulan jawa ditemukan bahwa kedua bunga tersebut sama-sama memiliki kelopak bunga yang berjumlah lima, yang menjadikan kelopak bunga tersebut memiliki karakteristik khas adalah warna serta corak yang terdapat pada permukaan kelopaknya. Hal yang

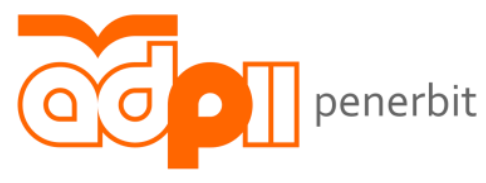

Penerbit Aliansi Desainer Produk Industri Indonesia 
membedakan kedua bunga tersebut adalah Rafflesia patma hanya memiliki satu bunga yang tumbuh menempel pada inangnya, sementara untuk anggrek bulan Jawa ia tumbuh dengan bunga yang bercabang pada batangnya.
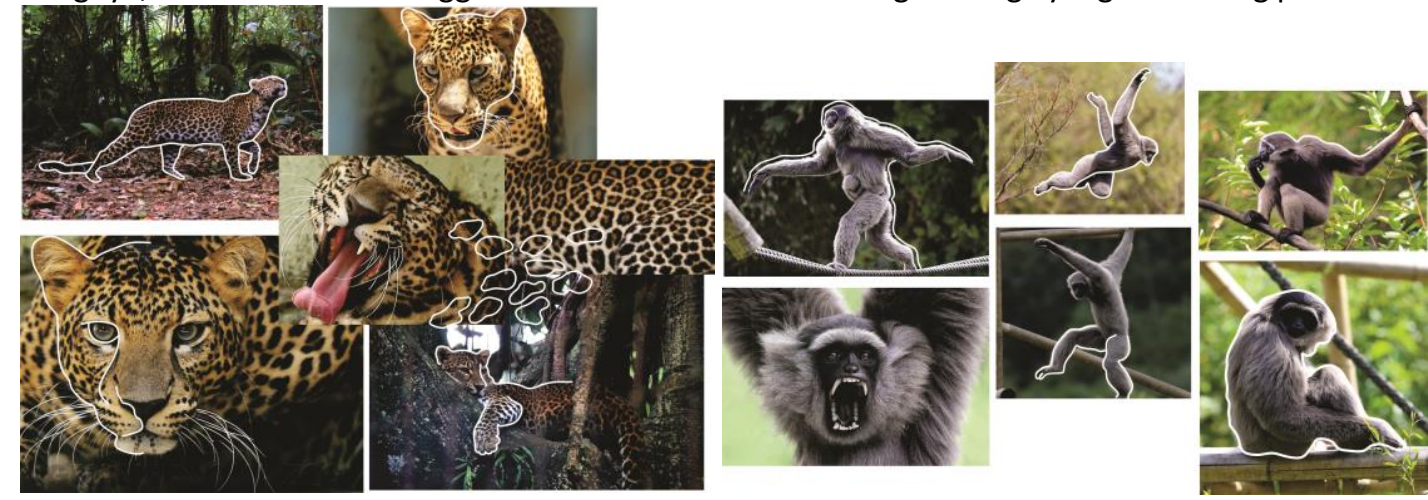

Page | 62

Gambar 5 Image board macan tutul jawa dan owa jawa khas Jawa Barat. (Sumber: google images)

Sementara untuk analisis image board pada hewan macan tutul jawa dan owa jawa, ciri khas yang mereka miliki cukup berbeda. Macan tutul jawa memiliki ciri khas pada bintik atau tutul yang ada pada sekujur tubuhnya, terutama pada bagian kepala tutul tersebut semakin berdekatan. Sementara untuk owa jawa ia memiliki kesan bentuk tangan dan kaki yang ringan namun kuat, serta bagian wajah yang lebih gelap dibandingkan warna tubuhnya.

Berdasarkan analisis image board yang telah dibuat, mereka memiliki satu kesamaan yang unik yaitu yaitu kesan contrast yang terdapat pada bagian tubuh berupa warna maupun corak. Selain itu bentuk tubuh atau kelopak bunga yang mereka miliki tidak memiliki siluet garis yang tajam. Keunikan ini dinilai dapat diaplikasikan ke dalam bentuk modul perhiasan dari keramik dengan teknik yang dikuasai industri yaitu handbuild serta penggarapan permukaan dengan color clay maupun glasir untuk menghasilkan corak dan warna yang diharapkan.

\subsubsection{Konsep desain}
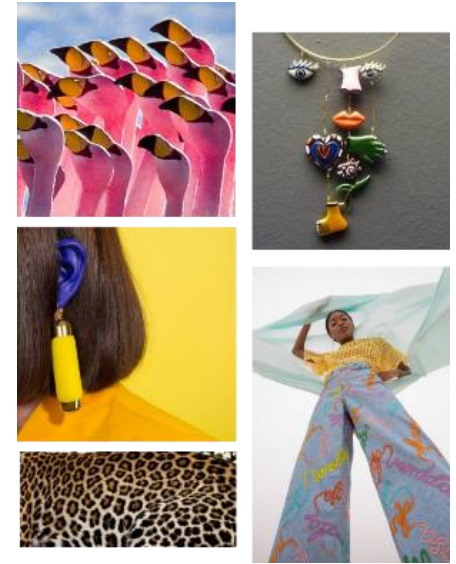

Gambar 6 Moodboard konsep. (Sumber: www.pinterest.com)

"Color coalition ceramic jewelry with the uniqueness characteristic of West Java's flora and fauna as an inspiration."

- Color coalition: Penggunaan banyak warna dengan teknik penggarapan color clay dan glasir.

- Ceramic jewelry: Perhiasan berupa anting dan kalung yang terbuat dari material keramik yaitu stoneware.

- Unique characteristic: Memanfaatkan keunikan yang dimiliki oleh sumber inspirasi sebagai desain perhiasan.

- West Java's flora and fauna: Bentuk figuratif terinspirasi dari flora dan fauna khas Jawa Barat.

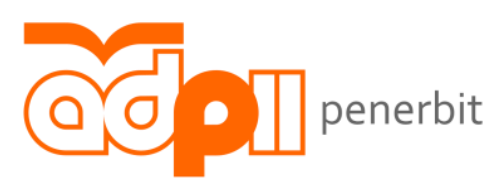

Penerbit Aliansi Desainer Produk Industri Indonesia 


\subsection{Alternatif desain}

Setelah melakukan analisis image board, diperoleh beberapa identitas kuat yang dimiliki oleh sumber inspirasi. Identitas tersebut kemudian divisualisasikan ke dalam bentuk gagasan sketsa dua dimensi. Gagasan berupa alternatif-alternatif sistem kuncian untuk modul keramik yang akan dikombinasikan dengan logam kuningan.
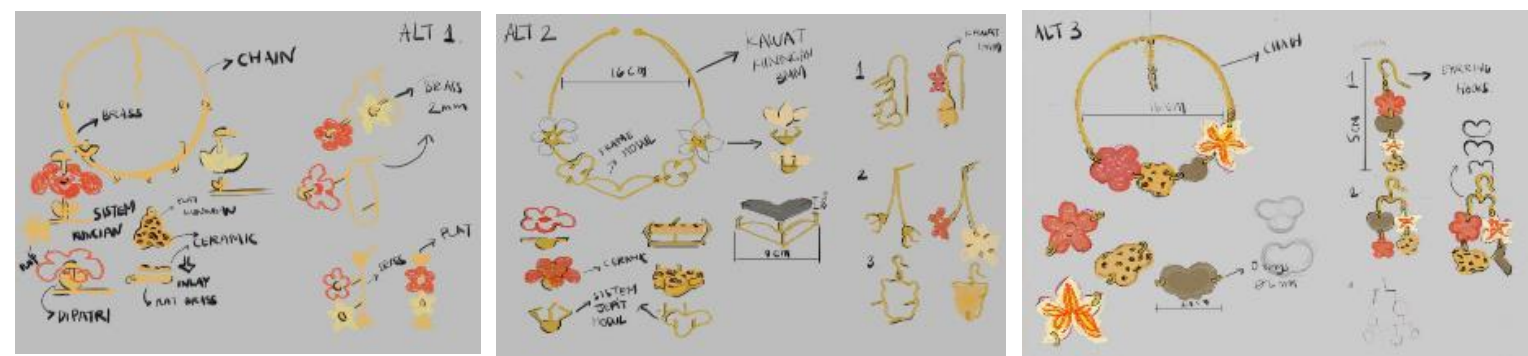

Page | 63

Gambar 7 Sketsa gagasan desain perhiasan. (Sumber: Data pribadi)

Selain memvisualisasikan gagasan ke dalam bentuk sketsa, dilakukan pula eksplorasi bentuk untuk menemukan bentuk modul perhiasan serta penyederhanaan bentuk pada objek tanpa menghilangkan keunikan yang dimiliki oleh sumber-sumber inspirasi.

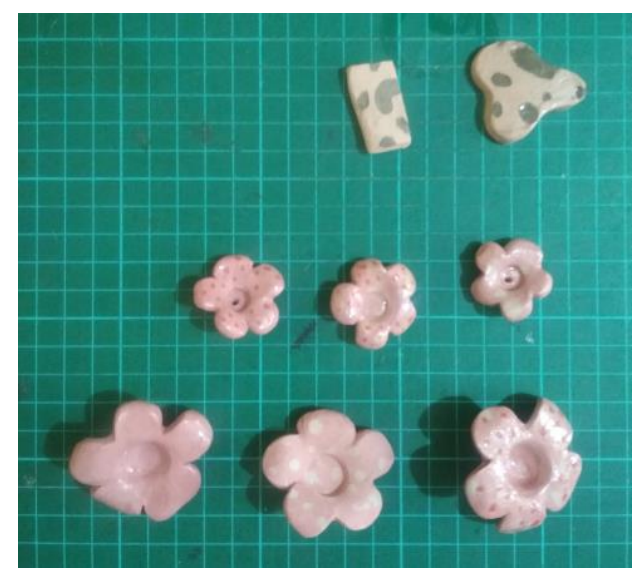

Gambar 8 Beberapa contoh hasil eksplorasi bentuk modul perhiasan. (Sumber: Dokumentasi pribadi)

Berdasarkan hasil analisis sketsa gagasan desain dan kemampuan material serta proses produksi, didapatkan empat buah sketsa desain yang dinilai sesuai dengan pertimbangan tersebut.
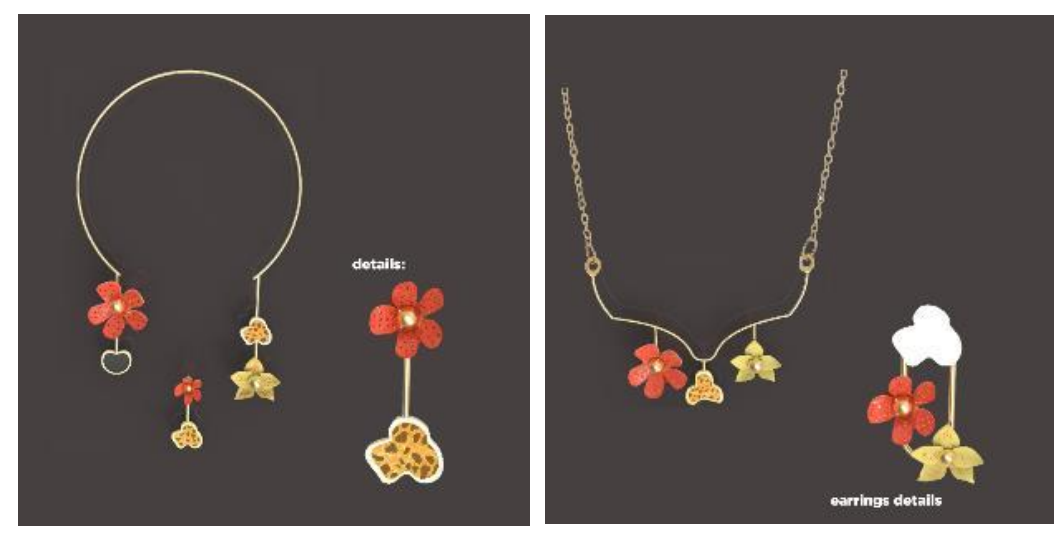
Jurnal Desain Indonesia Vol. 03 no. 01 - Aliansi Desainer Produk Industri Indonesia
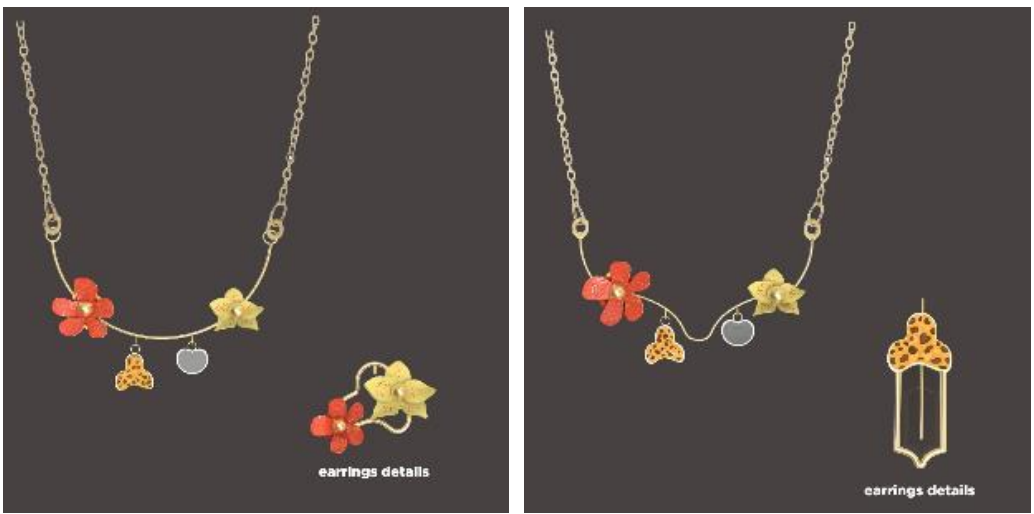

Page | 64

Gambar 9 Sketsa digital dari alternatif desain perhiasan. (Sumber: Data pribadi)

\subsection{Prototype}

Proses evaluasi desain dilakukan melalui penyebaran kuisioner pada target pengguna yang telah ditetapkan, hasil yang diperoleh ialah koresponden memilih sketsa desain yang tercantum di bawah ini.

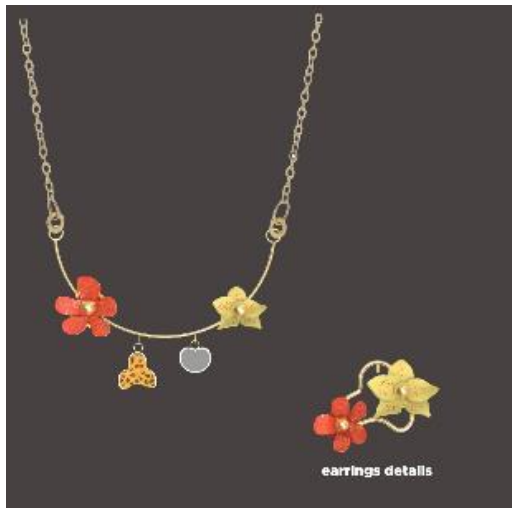

Gambar 10 Sketsa terpilih. (Sumber: Data pribadi)

Sketsa tersebut dinilai oleh koresponden lebih unggul dibandingkan alternatif sketsa lainnya dikarenakan desain perhiasan terlihat lebih sederhana, meskipun begitu perhiasan tetap memiliki kesan elegan. Selain itu, berdasarkan respon dari target pengguna pada kuisioner dapat disimpulkan bahwa beberapa alternatif desain masih terlihat rumit bagi sejumlah pengguna walaupun desain tersebut telah melewati proses penyederhanaan bentuk.
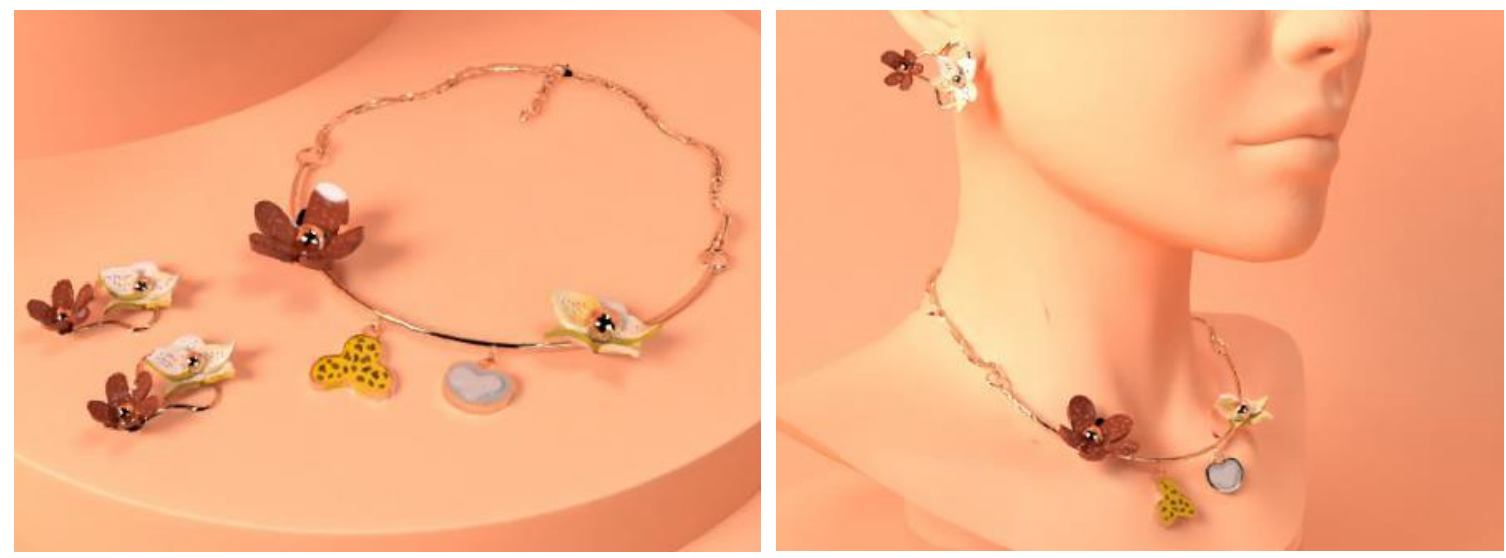

Gambar 11 3D modelling desain terpilih. (Sumber: Data pribadi)

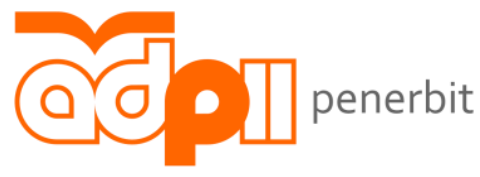

Penerbit Aliansi Desainer Produk Industri Indonesia 


\section{Kesimpulan}

Berdasarkan hasil proses analisis data dan studi model pembuatan modul keramik yang dilakukan oleh penulis, dapat disimpulkan bahwa penggunaan material stoneware dengan teknik color clay serta glasir memiliki peluang untuk dikembangkan oleh industri keramik lebih optimal baik dalam segi bentuk, warna, maupun penggarapan permukaannya. Dari proses pembakaran modul keramik didapatkan bahwa modul-modul keramik memiliki hasil yang sedikit berbeda antara satu dan lainnya walaupun memiliki proses pembentukan dan penggarapan permukaan yang serupa. Sehingga pada proses produksi selanjutnya akan lebih baik dan efektif bila proses pembentukan modul dilakukan menggunakan cetakan sehingga dapat meminimalisir adanya perbedaan bentuk pada modul keramik.

Pada hasil evaluasi sketsa desain yang dilakukan kepada target pengguna melalui kuisioner, dapat disimpulkan bahwa beberapa alternatif desain masih terlihat rumit bagi koresponden meskipun desain tersebut telah melewati proses penyederhanaan bentuk, target pengguna cenderung memilih perhiasan yang lebih sederhana namun tetap terlihat elegan. Sentuhan akhir pada material logam pun bisa dipertimbangkan berdasarkan selera target pengguna, dikarenakan ada pun pengguna yang tidak menyukai perhiasan dengan finishing gold. Maka dari itu pemanfaatan teknik electroplating pada logam dapat diaplikasikan oleh industri untuk memperluas target pasar yang akan dituju.

\section{Referensi}

[1] M. Husni and T. R. Siregar, Perhiasan Tradisional Indonesia, Direktorat Permuseuman, Direktorat Jenderal Kebudayaan, Departemen Pendidikan Nasional, 2000.

[2] T. A. Kardin, "BATUAN AGATE SEBAGAI INSPIRASI PADA PERHIASAN KERAMIK MENGGUNAKAN KOMBINASI MATERIAL LOGAM DENGAN TEKNIK AGATEWARE," Craft 1, vol. 1, 2012.

[3] D. Linda, R. Nathalie and T. Tochtermann, "A Multifaceted Future: The Jewelry Industry in 2020," pp. 3-6, 2014.

[4] I. M. Wayan, "Desain dan Teknik Produksi Keramik," Artikel Bulan Agustus, p. 1, 2011.

[5] R. A. Albugis, "PERANCANGAN PERHIASAN BAGI WANITA DENGAN MENGUSUNG KONSEP BATIK UDAN LIRIS SOLO MENGGUNAKAN MATERIAL KERAMIK DAN PERAK," Universitas Surabaya, Surabaya, 2019.

[6] A. Waskito, "Pendekatan Semantik Rupa Sebagai Metoda Pengembangan Desain Produk Dengan Studi Kasus Produk Mug di Industri Kecil Keramik," p. 5, 2014.

[7] M. N. Putri, "PEMANFAATAN TEKNOLOGI LASER CUTTINGDALAM PROSES PERANCANGAN PERHIASAN BERBAHAN AKRILIK LEMBARAN DENGAN PENDEKATAN EKSPLORASI BENTUK," Jurnal Desain Indonesia, vol. 2, p. 27, 2020.

[8] N. Rangkuti, I. Pojoh and N. Harkantiningsih, Buku Panduan Analisis Keramik, Pusat Penelitian dan Pengembangan Arkeologi Nasional, 2008.

[9] K. S. Arsa and N. Laba, "Diversifikasi Bahan dan Teknik Penciptaan Perhiasan Sebagai Pemenuhan Kebutuhan Gaya Hidup Masyarakat di Era Postmodern," MUDRA Jurnal Seni Budaya, p. 229, 2016.

[10] Vogue, "The Spring 2021 Jewelry Trend Report," Runway, 16 October 2020. 